\title{
Effects of web-based metacognitive listening on Chinese university EFL learners' listening comprehension and metacognitive awareness
}

\author{
Tao Pei* and Jitpanat Suwanthep \\ Suranaree University of Technology, 111 University Avenue, Muang District, Nakhon Ratchasima 30000, Thailand
}

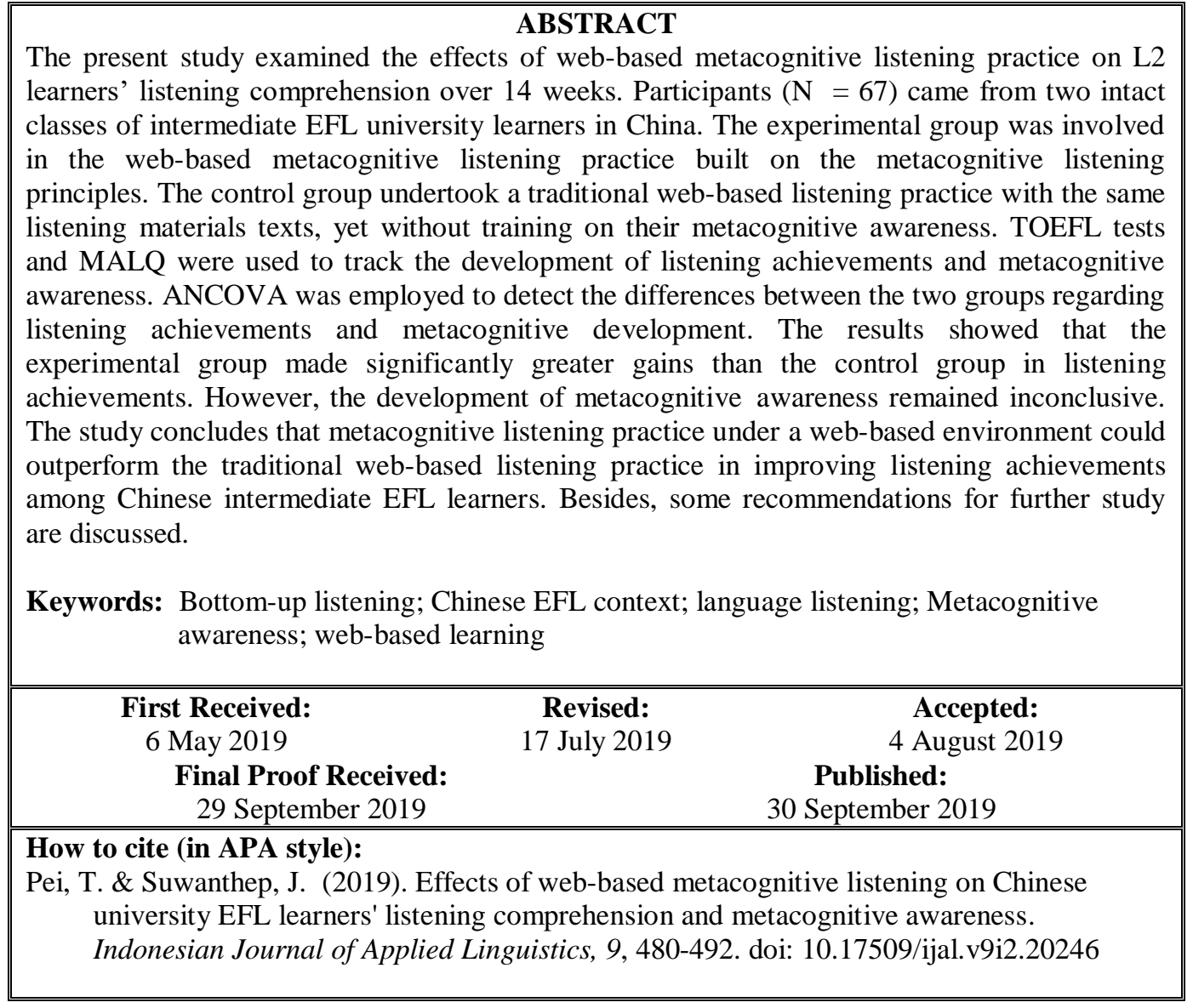

\section{INTRODUCTION}

The interests of language listening researchers and teachers are long unmatched (Berne, 1998). Although researchers have been highlighting the importance of raising learners' awareness of the listening process (e.g., Goh, 2008; Mendelsohn, 2001; Vandergrift, 2003a, 2004), the focus of language teachers is still on listening products rather than listening process (Fahim \& Fakhri, 2014). A recent study (Graham \& Santos, 2015) showed that language teachers assigned insufficient attention to the development of strategies and skills and "conceptualized [listening] as a pedagogical task to be completed rather than as a skill of communication" (p. 95). This study suggested that many language listening teachers lacked enough stress on teaching listening process and were still employing a test-oriented listening instruction rather than teaching how to listen (Mendelsohn, 1994; Siegel, 2015). The test-oriented or product-based listening instruction focused on learners' correct answers to listening comprehension questions without considering how to obtain the comprehension (Field, 2003; Goh 2008), resulting in more anxiety and ineffective use of strategies (Vandergrift, 2003a). Examination-oriented education is long established in China (Guo, Diaz, \& Liyanage, 2016; Hu \& West, 2015) or other East Asian countries which "focus on grades and high-stake testing" (Lee \& Zhou, 2015, p. 72). Chinese test-oriented culture is often regarded as an

\footnotetext{
* Corresponding Author

Email: pttongling@gmail.com
} 
objective way of selecting students to enter prestigious or commonplace higher institutions (Fang \& Warschauer, 2004; Huang, 2018). Due to some influential standardized tests such as College English tests, many Chinese university EFL teachers still adopted a test-oriented instruction approach, stressing improving learners' scores in tests (Wang, 2016; Huang, 2018). Meanwhile, since the English tests of the National College Entrance Exam (NCEE) in China revolved more around reading and writing, Chinese EFL students often ignored the training of listening before going to university (Wang, 2017). Therefore, it is advisable to continue research in guiding learners on how to listen, particularly in the Chinese context.

In the past decade, there has been a growing interest in metacognitive instruction of L2 listening. Many studies (e.g., Bozorgian, 2014; Cross, 2011; Mahdavi \& Miri, 2017; Vandergrift \& Tafaghodtari, 2010) on metacognitive instruction were conducted based on the cycle firstly proposed by Vandergrift (2004, 2007). This cycle could be viewed as a string of tasks "integrating everyday listening activities with metacognitive materials" (Goh, 2008, p. 199) in order to guide learners through the metacognitive process of planning, monitoring, evaluating, and problem-solving to make them self-regulated listeners (Vandergrift \& Tafaghodtari, 2010). To date, although most previous studies on metacognitive listening instruction have produced positive results on the improvement of listening abilities and metacognitive awareness (Graham \& Santos, 2015), unexpected findings still exist. Among these studies, some (e.g., Cross, 2011; Vandergrift \& Tafaghotari, 2010; Wang, 2016) showed that lessskilled listeners could outperform their skilled counterparts in both the development of listening achievements and metacognitive awareness; some (e.g., Bozorgian, 2014; Vandergrift \& Tafaghotari, 2010) revealed that learners could only benefit on some dimensions of metacognitive awareness such as planning-evaluation and problem-solving, but not on person knowledge (listeners' perceptions regarding listening difficulty and their self-efficacy in L2 listening.), (no) mental translation, and directed attention; still others (e.g., Taguchi, 2017) found no advantage of the metacognitive instruction over the traditional listening instruction in the development of listening abilities and metacognitive awareness. Although the mixed results from previous studies, a widely held view (e.g., Bozorgian, 2014; Cross, 2011; Vandergrift \& Tafaghotari, 2010) was established that only the less-skilled listeners could gain distinct benefits from metacognitive instruction. Therefore, there is a necessity to further explore and modify the model of metacognitive listening instruction to expand its effectiveness. One modification is the inclusion of bottom-up listening activities. A limitation with the mode of metacognitive instruction or Vandergrift's cycle is that it focuses on the training of top-down processing more than bottom-up processing of listening (Siegel, 2014). This could account for biased benefits towards the less-skilled listeners (Vandergrift \& Tafaghodtari, 2010). Therefore, researchers (Goh, 2008; Graham \& Santos, 2015; Vandergrift \& Tafaghodtari, 2010) have hypothesized that integrating bottom-up listening activities with metacognitive instruction would produce more robust results and benefit a wider range of learners. However, although checking up the transcripts after listening is common in most listening instruction, integrating diverse bottom-up listening tasks with metacognitive instruction is rarely seen in previous research studies. Thus the present study considers the integration of some bottom-up listening tasks into the metacognitive listening training.

\section{Web-based listening}

On the other hand, there is a continuing need to explore the instructional designs of L2 listening via the "functionality (e.g., use of captions)" and "interactivity (e.g., learners' control over help options)" (Vandergrift \& Cross, 2017, p. 7) under the multimedia environment. Some researchers have identified several advantages of improving listening achievements through web-based learning. Under web-based environment, (a) learners could control their own pace and listening speed in the listening (Robin, 2007); (b) learners could repeat listening (Verdugo \& Belmonte, 2007); (c) learners could receive immediate feedback (Hoven, 1999) given by teachers or check comprehension on their own; (d) learners could be exposed to more listening resources and teachers could receive more professional skills in listening instruction (Chen \& Zhang, 2010).

However, it is still mysterious whether learners' listening achievements could be better enhanced under the web-based learning environment. Previous studies have shown mixed findings on this issue. For instance, Absalom and Rizz (2008) and Sun, Chang, and Yang (2011) have indicated that the learners who received online listening tasks could perform better in listening comprehension or retain more information than those who did not. However, in Chen and Zhang (2010), the learners who received an advanced online listening system did not make greater gains than those who received traditional listening instruction. Despite the mixed findings, Paulsen (2001) noted that it is "no longer a question of whether to take advantage of these electronic technologies in foreign language instruction, but of how to harness them and guide our students in their use" (para. 2). Meanwhile, researchers (e.g., Kung \& Chuo, 2002; Leloup \& Ponterio, 2007; Sun et al., 2011) have agreed that teachers need to give students appropriate supports in online learning and try to integrate online learning tasks with classroom instruction. Besides, the exploration of listening training in blended learning could promise to facilitate autonomous listening (Maher, 2019; Penland, 2015). Therefore, linking metacognitive listening with blended learning may supplement the in-class listening instruction which, such as in the Chinese university context, often lacks enough focus on the listening process. Up to date, rare studies (e.g., Barcena \& Read, 
2015) have considered metacognitive listening training in an out-of-classroom setting under the multimedia environment and no studies have integrated the metacognitive instruction cycle into a web-based selflistening environment. Thus, it should be a promising attempt to employ the rich functionalities of a webbased environment to realize metacognitive listening practice to supplement classroom instruction and make a self-regulated listener outside the classroom.

Given this, the present researchers built up a listening practice website based on the metacognitive instruction cycle (Vandergrift, 2004, 2007) with the integration of bottom-up listening tasks. This study aims to investigate the effects of web-based metacognitive listening practice on Chinese EFL learners' listening achievements and metacognitive awareness.

\section{METHOD}

\section{Research design}

The present study adopted a mixed-method design. The quantitative part involved a quasi-experiment method with a pretest-posttest control group design. The independent variables were learners' listening levels and two types of treatment: the web-based metacognitive listening practice and the traditional web-based listening practice. The dependent variables were learners' listening achievements and metacognitive awareness. The qualitative part was a semi-structured interview after the experiment. The purpose of the qualitative design was to elaborate on the results from the quantitative method.

\section{Research participants and sites}

Two intact classes of $67 \mathrm{EFL}$ students (intermediate level) from a second-tier Chinese university participated in the study. Since second-tier universities occupy the largest number of universities in China, these participants could roughly represent Chinese university students. Out of the primary enrollment of 100 learners, 33 students were excluded due to their failure to participate or complete all the listening practice. All participants signed informed consent forms before the experiment and were free to withdraw the study. Because of no initial differences in listening proficiency between the two intact classes, they were randomly assigned to one experimental group $(\mathrm{N}=32)$ and the control group $(\mathrm{N}=35)$. Learners in both groups were further divided into skilled and less-skilled listeners according to their pre-test TOEFL listening scores: those scoring above the mean were recognized as skilled listeners and those below the mean as the less-skilled listeners (Vandergrift \& Tafaghodtari, 2010). The experimental group consisted of 11 skilled and 21 lessskilled listeners; the control group consisted of 19 skilled and 16 less-skilled listeners.

\section{Research instruments and data collection technique} Listening achievements were measured using the listening sections of two TOEFL sample tests as pre- and post-tests. As a well-known standardized English test, TOEFL was developed and administered by Educational Testing Service (ETS). TOEFL listening sections had high reliability (ETS, 2011) and criterionrelated validity (Sawaki \& Nissan, 2009). The sample tests came from the book The Official Guide to the TOEFL IBT (ETS, 2017), the only official guide developed by ETS. Therefore, the reliability and validity of the listening sample tests could be guaranteed. The raw TOEFL Scores were converted into the scale scores according to the instruction of the book.

Metacognitive awareness was measured using the MALQ (see appendix) at the beginning and end of the experiment. This questionnaire was robustly developed and validated by Vandergrift, Goh, Mareschal, and Tafaghodtari (2006). This questionnaire consists of 21 items, underpinned by five factors: planning and evaluation, directed attention/concentration, person knowledge, (no) mental translation, and problemsolving (Vandergrift et al., 2006). Many studies (e.g., Bozorgian \& Alamdari, 2018; Mahdavi \& Miri, 2017; Rahimi \& Katal, 2013) revealed that the internal consistency reliability of this questionnaire was above an acceptable level (the coefficient alpha >.70). To increase the intelligibility, the researchers translated each item of the questionnaire into Chinese. The coefficient alpha of the translated MALQ in the present study is 0.85 .

A semi-interview was conducted after the experiment to elicit learners' responses on their perceptions of the development of listening ability and metacognitive awareness as well as listening confidence and problems in dealing with listening tasks. 7 skilled listeners and 9 less-skilled listeners in the experimental group were randomly selected to receive the postinterview with their consent. The overall number $(\mathrm{N}=16)$ of interviewed participants exceeded the rational number of gaining saturation $(\mathrm{N}=12)$ in interviews (Guest, Bunce, \& Johnson, 2006). A pilot study revealed that learners had no problems in understanding the items of the questionnaires and interview questions.

\section{Treatments}

The researchers made two websites for the experimental and the control group using the WordPress platform. From week 2 to week 15, both experimental and control groups took out-of-class web-based listening practice as a supplement to their in-class listening lessons. The information on activity duration, history, and learners' responses were tracked by the researchers via the websites' admin panel, as learners had to log into these websites with assigned accounts and passwords. Learners were encouraged to contact the researchers if they met some problems during listening practice. The listening materials for the websites were the video lectures and news of a normal speech rate, around $140 \pm$ 20 wpm (Baker, Downton, \& Newell, 1980) and within the time length from 3-5 minutes. The topics were close to those in the learners' listening textbooks. Both experimental and control groups received an in-class 
listening course for 90 minutes one week which was taught by a Chinese English teacher with 10-year teaching experience. The researchers received consent from the teacher for experimenting but without revealing the details of the experiment.

\section{Experimental group}

For 14 weeks, participants in the experimental group did two sets of listening practices each week. The listening practice was mainly built based on Vandergrift's (2004) metacognitive listening cycle by guiding learners through the metacognitive listening processes of planning, monitoring, evaluating, and problem-solving. Meanwhile, two bottom-up listening tasks: dictation and reading-while-listening, were placed near the last stage of listening. These two tasks have been proven effective in improving listening achievements by previous studies (e.g., Chang, 2009; Kiany \& Shiramiry, 2002).

The practice consisted of 5 sub-stages:

- In the planning stage, learners were required to read listening topics and some difficult words. Then they answered some questions to set goals, plan their listening strategies and possible problems, and make predictions of information and possible words.

- Learners listened to materials for the first time. Then they verified their predictions and evaluated the effectiveness of strategies and their listening problems before the second listening.

- Learners listened to materials for the second time. Then they verified their listening again, supplemented missing information in their first listening, evaluated their listening skills, and summarized the listening.

- Learners listened to materials for the third time. While listening, they were required to complete the sentential dictation tasks or read aloud the transcripts. Then they noted down difficult words and evaluated their performance.

- In the last stage, learners were required to reflect on their strategy use and listening problems.

The interface of the web-based metacognitive listening practice was shown in Figure 1.
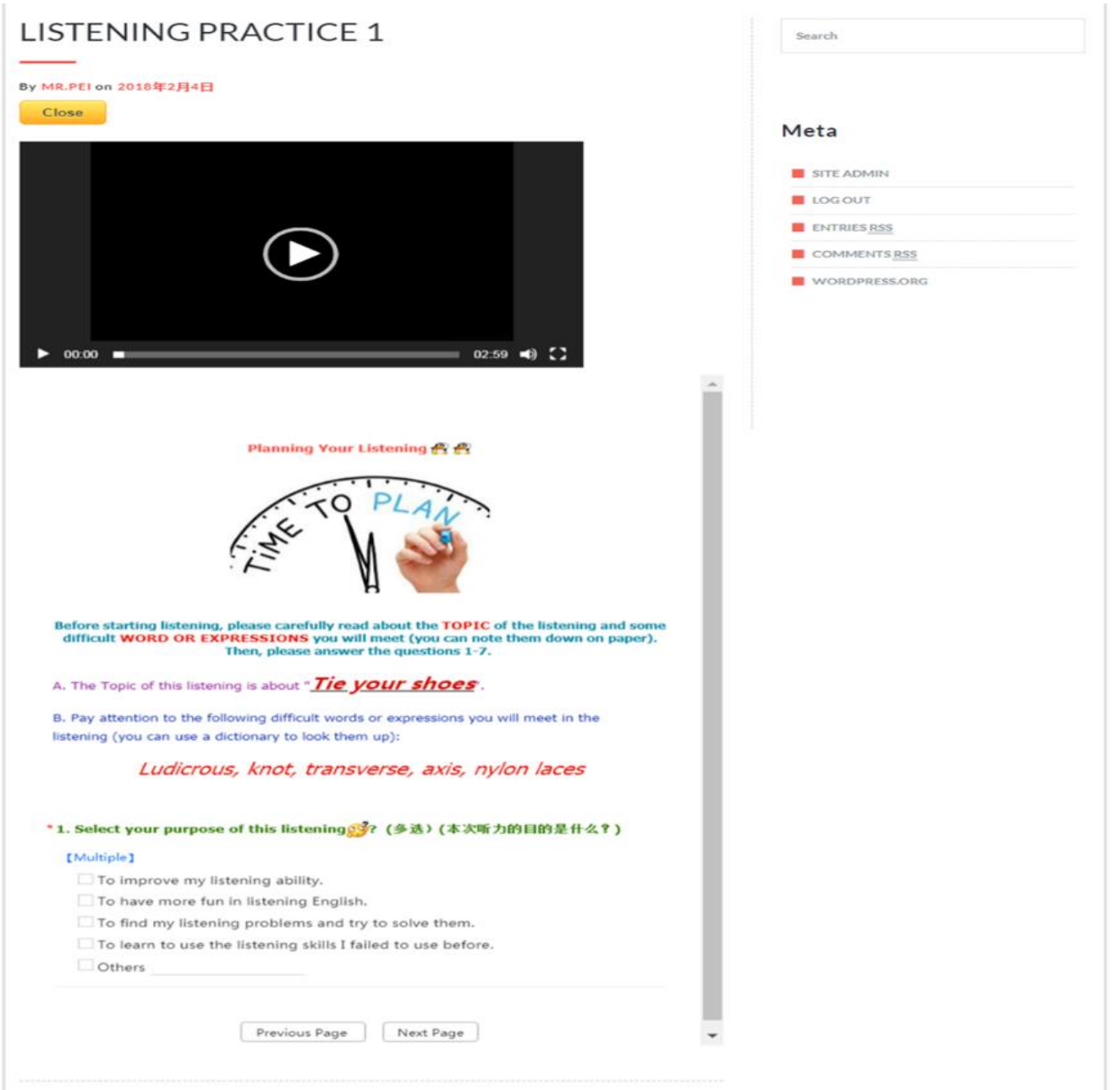

Figure 1. The interface of the web-based metacognitive listening practice 
Additionally, there is a section of listening skills on the experimental group website, introducing the knowledge of listening strategies. Learners could check this knowledge at any time. Besides the weekly listening practice, the experimental group was also asked to keep weekly online journals to reflect on their listening strategies and problems and submit them each week. The reflection journals were designed to provide more opportunities for learners to make a reflection on their listening process. They could be regarded as part of the web-based metacognitive practice. This operation was also documented in Wang (2016). The interface was designed in the way that learners could not move to the next stage until they finished tasks in the current stage.

\section{Control group}

Another website was made for the control group. They were required to listen to the same videos each week for at least three times and then summarize their listening on the website. Since these tasks for the control group were less demanding than those given to the experimental group, the control group was also asked to complete an extra multiple-choice listening comprehension task on the website each week. The control group did not keep reflection journals and receive the interview.

\section{Data analysis}

Data from listening tests and MALQ were analyzed through SPSS 13.0. ANCOVA was used to examine the differences in listening achievements and metacognitive awareness between two groups, with pre-test scores as covariates. The significant $\mathrm{p}$-value was set at 0.05 . Content analysis was used to detect emergent themes in the interview data. The emergent themes were found regarding learners' perception of the development of listening proficiency, metacognitive awareness, and their perception of metacognitive listening practice.

\section{RESULTS \\ Listening achievements}

In order to answer the first question, the researchers used two-factor ANCOVA to identify the variance in listening achievements. The independent variables included the group (the experimental or control group) and the listening ability level (skilled or less-skilled). The post-test scores of TOEFL tests were set as the dependent variable and pre-test scores as the covariate. The researchers examined the Levene's test of equality of error variance, indicating the data had the homogeneity of variance $(\mathrm{F}=2.38, \mathrm{p}=.08)$. As shown in Table 1, the group variable produced a significant effect on the variance of listening achievements $(\mathrm{F}=$ $10.04, \mathrm{p}=.00$ ), with $\eta 2=.14$ showing a medium effect.

In reference to Table 2, the mean scores of the experimental group were larger than that of the control group in the post-test, so we could conclude that the web-based metacognitive listening practice exerts a significant impact on the learners' listening achievements. Meanwhile, since there was no significant interaction between group and proficiency levels $(\mathrm{p}=.77)$ plus the observed significant effect on the group variable $(\mathrm{p}=.00)$, it could be concluded that both skilled and less-skilled listeners in the experimental group outperformed their counterparts in the control group in terms of listening performance.

To sum up, both skilled and less-skilled listeners in the experimental group significantly outperformed their counterparts in the control group in terms of listening achievements.

Table 1. L2 listening achievements as a function of group and listening level with pre-listening as a covariate

\begin{tabular}{lrrrrr}
\hline Source & df & M & F & Sig. & $\eta 2$ \\
\hline Group & 1 & 129.40 & 10.04 & .00 & .14 \\
Listening Ability Level & 1 & 11.73 & .91 & .34 & .01 \\
Group * Level & 1 & 1.09 & .09 & .77 & .00 \\
Pre-Listening & 1 & 1.91 & .15 & .70 & .00 \\
Error & 62 & 12.88 & & & \\
\hline
\end{tabular}

Table 2. Means and standard deviations of pre- and post-listening scores

\begin{tabular}{lrrrrr}
\hline & \multicolumn{3}{c}{ Pre-Test } & \multicolumn{2}{c}{ Post-Test } \\
\hline Source & N & M & SD & M & SD \\
\hline E-Group & & & & & \\
\hline High & 11 & 11.86 & 1.83 & 12.73 & 3.07 \\
Low & 21 & 7.05 & 1.97 & 10.38 & 2.96 \\
Total & 32 & 8.70 & 3.00 & 11.19 & 3.16 \\
\hline C-Group & & & & & \\
\hline High & 19 & 12.87 & 1.57 & 9.68 & 3.74 \\
Low & 16 & 5.97 & 1.99 & 7.69 & 4.32 \\
Total & 35 & 9.71 & 3.90 & 8.77 & 4.08 \\
\hline
\end{tabular}

* E-group means the experimental group and C-group means the control group

\section{Development of metacognitive awareness}

In order to answer the second question, the researchers continued to use several ANCOVAs to identify the variance on the five factors in MALQ, namely, planning and evaluation, directed attention, person knowledge, (no) mental translation, and problem-solving. The pretest scores of these factors in MALQ were used as the covariates. The Levene's test of equality of error 
variance showed the homogeneity of variance on the data of planning and evaluation $(\mathrm{F}=1.60, \mathrm{p}=.21)$, directed attention $(\mathrm{F}=.12, \mathrm{p}=.95)$, person knowledge $(\mathrm{F}=1.60, \mathrm{p}=.20),(\mathrm{no})$ mental translation $(\mathrm{F}=2.12, \mathrm{p}$ $=.11)$, and problem-solving $(\mathrm{F}=.22, \mathrm{p}=.88)$. Table 3 showed that the group had a significant impact on the factors of person knowledge $(\mathrm{F}=4.04, \mathrm{p}=.05)$ and (no) mental translation $(\mathrm{F}=4.81, \mathrm{p}=.03)$. The interaction effects were not detected in all these factors.

In reference to Table 4 , it can be observed that despite the significant findings, the control group $(\mathrm{M}=$ $2.72 ; \mathrm{M}=2.99$ ) outperformed the experimental group $(\mathrm{M}=2.36 ; \mathrm{M}=2.48)$ on the two factors in the posttest.

Table 3. Univariate tests on factors of metacognitive awareness

\begin{tabular}{llrrrr}
\hline \multicolumn{1}{c}{ Source } & \multicolumn{1}{c}{ Measure } & df & Mean Square & \multicolumn{1}{c}{ F } & \multicolumn{1}{l}{ Sig. } \\
\hline Group & Planning and evaluation & 1 & .70 & 2.17 & .15 \\
& Directed attention & 1 & .06 & .14 & .71 \\
& Person knowledge & 1 & 2.01 & 4.04 & .05 \\
& No translation & 1 & 2.90 & 4.81 & .03 \\
& Problem-solving & 1 & .39 & .70 & .41 \\
\hline Group* Level & Planning and evaluation & 1 & .15 & .46 & .50 \\
& Directed attention & 1 & .00 & .00 & .99 \\
& Person knowledge & 1 & .47 & .94 & .34 \\
& No translation & 1 & .18 & .29 & .59 \\
& Problem-solving & 1 & .02 & .04 & .85 \\
\hline
\end{tabular}

Table 4. Means and standard deviations of person knowledge and no translation for the two groups

\begin{tabular}{lcccc}
\hline & Pre-Test & \multicolumn{3}{c}{ Post-Test } \\
\hline Source & $\mathbf{M}$ & SD & M & SD \\
E-Group & & & & \\
Person Knowledge & 2.61 & 1.03 & 2.36 & .93 \\
No Translation & 2.88 & .95 & 2.48 & .82 \\
C-Group & & & & \\
Person Knowledge & 2.62 & .92 & 2.72 & .94 \\
No Translation & 3.10 & .79 & 2.99 & .83 \\
\hline
\end{tabular}

In sum, the analyses related to the second question reached an unexpected result that the control group outperformed the experimental group in both the metacognitive factors of person knowledge (marginally significantly, $\mathrm{p}=.05$ ) and (no) mental translation (significantly, $\mathrm{p}=.03$ ). The results on (no) mental translation were partly consistent with Vandergrift and Tafaghodtari (2010). Vandergrift and Tafaghodtari (2010) found that the experimental group showed more reported use of mental translation strategy after metacognitive listening treatment than the control group From the thinking aloud protocols, they indicated that their participants did not actually "engage in word-forword translation but often appear to confound word recognition and inferencing with translation" (p. 487). Meanwhile, these findings might also be explained from the following post-interview data.

\section{Results from interview data}

Data from the post-interview provided further insights into the development of listening achievements and metacognitive awareness. Analysis of these interviews confirmed the reported growth in listening abilities and mixed results in the development of metacognitive awareness. To ensure anonymity, the researchers used the name codes for interviewees in the data reporting, with the skilled listeners labeled $\mathrm{S}$ plus the number (e.g., $\mathrm{S} 1, \mathrm{~S} 2)$ and the less-skilled listeners $\mathrm{L}$ plus the number (e.g., L1, L2).
First, Excerpt 1 showed that both skilled and lessskilled listeners acknowledged the improvement of their listening ability and comprehension, especially of quicker and lengthier listening materials.

Excerpt 1

Listening ability, yes, at the very beginning, it was really fast...Now I could understand some of them. (S2)

Now I can understand a sentence...Listening ability. It is improved, of course, as I have practiced for one semester. (S7)

In the past, I felt very anxious about some lengthy listening materials and was easy to give them up. But now after one semester I could finish the tasks and understand almost half of the content. (S4)

Now I become more patient and understand more (than before). Sometimes, I don't need to watch the video but just listen (and get the understanding). (L3)

Then, Excerpt 2 indicated some learners' perceived improvement of the awareness in the metacognitive listening process of planning, monitoring, and evaluation to become a self-regulated listener.

Excerpt 2

I think in the past, we practiced listening in an unsystematic way. Through the practice, we have 
learned to predict, do something before listening and write something while listening. It is a complete process. In the past, we just practiced listening and answered questions directly. (L3)

Now, I feel I am more strategic in listening because in the past, I felt anxious when I could not understand. Now the website guides me step by step through the listening process and also I could read some strategies on the website. I am not anxious even when I could not understand something. I could assign attention to other parts. (L9)

Furthermore, Excerpt 3 demonstrated some learners' increased awareness of strategy use in listening.

\section{Excerpt 3}

Listening skills, I think, certainly they are helpful. For instance, you could take brief notes while listening. It is very important...in the past; I did not know the prediction... (L1)

Listening skills are very helpful for listening... For me, from high school until now, I think to grasp the key words is very important...I repeat listening and make notes... and focusing is very important. I often find a quiet place and nobody can interrupt me. (L5)

In the past, I often translated in my mind when listening. Also, now I am gradually changing this habit. (S4)

I think I know more listening skills such as prediction...In the past, I like translating (all information) in my mind and now I think it is not good. I think understanding key information is more important than the total. (S5)

I think the prediction is the most helpful listening skill. Sometimes, you could listen for details when you fail to listen to the whole content and predict some information. (S7)

The above excerpt indicated that the participants from both skilled and less-skilled groups like L2, S5, and S7 showed the increased awareness of the importance of prediction, suggesting that these participants were willing to do planning before listening.

The quantitative results showed that the experimental group made little improvement in the strategy of "(no) mental translation." The above excerpt could provide some insights into this finding. S4 said that she learned the strategy of "(no) mental translation." However, S5 seemed to have misinterpreted "I like translating" into "I like understanding" because she showed a contrast between what she focused on in the past and present. Therefore, the item of "I translate in my mind as I listen" in the MALQ might be interpreted as "I understand in my mind as I listen" by some learners. Accordingly, another item "I translate key word as I listen" would be interpreted as a useful strategy of selective attention. Besides, as shown in Excerpt 4, L6 saw translation as affective strategy to reduce anxiety.

\section{Excerpt 4}

Now the problem is that I always want to translate English into Chinese while listening, but I also find I cannot because the listening is too quick... I don't know why. Every time I listen, I try to translate. If I don't translate, I am anxious... because I feel if I don't translate, I cannot understand. (L6)

The above excerpt indicated that these learners' decreased use of (no) mental translation could be explained by their misinterpretation of some MALQ items which reflects their increased selective attention and affective strategies.

In addition, Excerpt 5 showed the mixed perceptions of the increased person knowledge of listening confidence.

\section{Excerpt 5}

Now I have more confidence [of listening], that is, I am not afraid of it [listening] or feel nervous. (S5)

I didn't have any improvement in listening confidence. (L6)

Confidence, sometimes I have it but sometimes I don't have it. Today I took a listening class and I didn't have confidence because I made a lot of mistakes in listening practice. (S2)

I'd say I am confident in doing a listening practice like this but when it comes to tests... [I still feel nervous]. (S7)

The above excerpt could provide further insights into another surprising finding that the experimental group showed a significant decrease in person knowledge. Although S5 stated the improvement of listening confidence, L6 showed no improvement in listening confidence. Still others (like S2 and S7) thought that listening confidence relied on different tasks. These statements showed that learners bore mixed feelings toward listening confidence, an important source of person knowledge. The fluctuation of listening confidences indicated by S2 and S7 indicated learners' unstable person knowledge towards L2 listening. On the other hand, these learners' reduced person knowledge may also be impacted by learners' experience towards the website design and metacognitive questions as shown in Excerpt 6.

\section{Excerpt 6}

It always asked some repetitive questions. I think these questions could be asked every month to examine the improvement [of strategy use]. (L5) 
Some questions made me in a fret. There were too many repetitions[of questions]... At last I was impatient and chose them randomly. (S5)

When I finished the practice, the page just collapsed, and I had to redo the practice, I felt angry. (S2)

I dare not press the back button. When I pressed it, the practice page would collapse and I had to redo the practice. It was very irritating. (S4)

Excerpt 6 showed learners' complaints about the repetitive questions and lack of functionality to automatically save their answers while taking the practice, resulting in the irritating and fretful experience. According to Bandura (1994), the mastery experience is the most influential source of self-efficacy; success builds a robust sense of efficacy while failures undermine it. Therefore, these unpleasant experiences might undermine learners' self-efficacy of listening under the web-based environment, as part of the person's knowledge of listening.

In summary, the interview data showed that learners in the experimental group indicated their improvement in listening achievements and the metacognitive awareness of planning, monitoring, and evaluating their listening process. Their awareness of some listening strategies, such as prediction and selective attention was also improved. However, their perceived person knowledge of listening and the awareness of (no) mental translation remained uncertain. These results partially corresponded with those obtained from the quantitative data, where the control group overtook the experimental group regarding developing these two dimensions. The following section discusses these results.

\section{DISCUSSION}

Results from statistical analysis showed that both skilled and less-skilled listeners improved their listening achievements after the metacognitive listening practice in comparison with the control group. This finding was also confirmed by the post-interview data, as both skilled and less-skilled listeners perceived the improvement of listening achievements. Our results confirmed the findings of the early studies (e.g., Bozorgian, 2014; Cross, 2011; Vandergrift \& Tafaghodtari, 2010) reporting the beneficial effects of web-based metacognitive instruction on listening achievements. Meanwhile, we detected more robust results for skilled listeners than those reported by Cross (2011) and Vandergrift and Tafaghodtari (2010). Some researchers (Goh, 2008; Graham \& Santos, 2015; Siegel, 2014; Vandergrift \& Tafaghodtari, 2010) have assumed that adding a bottom-up section in web-based metacognitive instruction could produce more robust results and even benefit the high-proficiency learners. This assumption is, therefore, confirmed in the present study.
The effects on the learners' development of metacognitive awareness remained unsettled. The quantitative data, in general, indicated no better improvement in metacognitive awareness by the experimental group. However, interview data revealed some improvement in metacognitive awareness by this group. Thus, we inferred that the control group had also made some improvements in metacognitive awareness. This could partially be explained by the exposure to MALQ statements by the control group in the two times of administration. When selecting the degree of agreement with items listed in the questionnaire, they could make reflections on the metacognitive process in L2 listening. This reflection could potentially raise their metacognitive awareness (Bozorgian, 2014; Vandergrift \& Tafaghodtari, 2010). Next, as the present participants were intermediate learners who had learned English for more than 12 years, perhaps they already had abilities to regulate their metacognitive and cognitive listening process during listening (Vandergrift, 2003b), limiting the room for development. Besides, from the interview data, we found some learners complained about the excessive metacognition-induced questions which required them to plan, monitor, and evaluate their listening process, leading to impatience and fretfulness. Negative emotions have been shown to decrease learners' achievements (Pekrun, Elliot, \& Maier, 2009) and negatively impact higher-order cognitive processes (such as problem-solving and strategic thinking) (Fredrickson, 2001; Valiente, Swanson, \& Eisenberg, 2012). Thus, these negative emotions from the disagreeable experiences would affect their involvement in metacognitive training and the development of metacognitive awareness.

The most counterintuitive results were found on the dimensions of person knowledge and (no) mental translation. The quantitative results demonstrated that the experimental group showed a significant decrease in the two dimensions of metacognitive awareness compared with the control group. The surprising findings on person knowledge could be explained with qualitative results. The qualitative data revealed an unstable and mixed perception of person knowledge of listening confidence, that is, learners' views on listening confidence depend on specific listening tasks. This instability made it challenging to measure learners' person knowledge of listening with MALQ accurately. On the other hand, learners' complaints of the website experiences and question-setting in the experimental group would result in failed learning experiences, affecting their self-efficacy of completing the listening tasks (Bandura, 1994), as part of the person's knowledge (Vandergrift \& Goh, 2012). On the other hand, the website for the control group which had fewer functionalities and simpler question-settings might produce fewer complaints regarding these elements and bring about more successful learning experiences.

The unexpected results on (no) mental translation in quantitative data could also be discussed with the interview data. According to Vandergrift and 
Tafaghodtari (2010), learners might misinterpret the mental translation as a strategy of word recognition, prediction, and selective attention (to keywords). Our interview data partially confirmed this statement. Some learners did misinterpret the translation as "understanding" and selective attention strategies or took the translation strategy as a way of reducing anxiety. In this case, learners might be confounded with the effectiveness of (no) mental translation strategy, leading to mixed results on this dimension. Additionally, some learners felt they were overloaded with metacognition-induced questions, probably inducing their hasty responses to questions. If learners consistently made such responses in metacognitive questions, they would be more likely to move to the bottom-up listening practice on the website without gaining much comprehension. This would increase the risk of developing their inefficient online translation approach to listening (Eastman, 1991; Vandergrift, 2008) leading to their decreased use of (no) mental translation strategies during listening.

This discussion steers our attention to the important role of learners' experiences in web-based learning. Lack of better metacognitive development by the experimental group may be due to their undesirable experiences in answering metacognitive questions and facing some technical problems. Reeves and Reeves (1997) indicated that although web-based learning could engage learners due to diverse functionalities, such attraction may not last a long time. In the classroom instruction, learners could get instant feedback and encouragement from the teachers or partners when problems on the task design and technology arise. But when these problems happen in a web-based selflearning environment, they are more likely to generate learners' negative emotions and undesirable experiences due to limited scaffolding from others. Therefore, language teachers need to offer more guidance or scaffolding for learners to sustain learning in the webbased environment (Kung \& Chuo, 2002; Lu, 2010; Sun et al., 2011). Previous literature has also noted the benefits of the support on learners' person knowledge. In Graham and Macaro (2008), some learners received constant feedback on their journals to identify the benefits of the strategy use and confidence and showed the improvement of listening self-efficacy.

Although the development of metacognitive awareness stays unclear, the learners' improvement in listening achievements could indicate the positive role of the bottom-up training in the practice. Previous researchers have observed that metacognition could only account for the limited variance of listening comprehension, that of 13\% (Vandergrift et al., 2006), $3 \%$ (Tafaghodtari \& Vandergrift, 2008), 22\% (Goh \& $\mathrm{Hu}, 2013)$. So, still, a large portion of listening variance could be explained or determined by other factors such as linguistic knowledge, memory capacity, bottom-up skills, social-affective factors and so on (Vandergrift \& Goh, 2012). This result in some way also reemphasized the importance of bottom-up skills training as constantly highlighted by some previous researchers (e.g., Field, 2008; Lynch \& Mendelsohn, 2013).

\section{CONCLUSION}

The present study indicates that metacognitive listening practice could significantly improve the Chinese intermediate-level university EFL learners' listening achievements. The improvement in listening achievements was witnessed on both the skilled and less-skilled listeners. However, the development of metacognitive awareness was still open to question. The experimental group did not show better improvement in metacognitive awareness than the control group. The unexpected findings might be due to learners' unpleasant experiences regarding task setting and technical problems, leading to their inactive engagement into the metacognitive process, reduced person knowledge, and more focus on bottom-up listening practice and online translation. The study also provided a sample for L2 teachers to design the web-based metacognitive listening practice outside the classroom, which could supplement their listening instruction inside the classroom.

However, this study also has some limitations which deserve further modification and exploration. Firstly, since learners may be easily discouraged with repetitive tasks due to lack of immediate feedback from teachers and peers, there is a need for greater diversity in metacognitive activities, especially in the online environment (Goh, 2008; Vandergrift \& Tafaghodtari, 2010). Meanwhile, learners' exposure to different types of tasks may "promote the transfer of metacognitive strategies across a variety of listening contexts" (Cross \& Vandergrift, 2018, p. 3). Secondly, enough scaffolding or feedback from teachers, either technical or strategic (as shown in Graham \& Macaro, 2008) could be promptly given to learners to sustain the learning engagement (Stavredes \& Herder, 2013), "their sense of personal control" (Graham \& Macaro, 2008, p. 755) and enjoyable experiences. Thirdly, the present web-based listening practice did not make possible the ongoing discussion as in the metacognitive instruction. Previous research has indicated the effective role of learner interaction or discussion on the development of learners' listening motivation (Cross, 2011), listening metacognition (Bozorgian \& Alamdari, 2018; Mahdavi \& Miri, 2017) as well as listening skills in diverse task conditions (Saito \& Akiyama, 2018), which could contribute to the improvement of overall listening comprehension. Although quite challenging, it is still beneficial to encourage learners' interaction during online metacognitive listening practice. Thus, further research could consider involving diverse listening activities, learners' scaffolding, and learners' interaction within the present web-based metacognitive listening practice, which may produce more robust findings. Lastly, the integrated bottom-up sections in the study might play a positive role in improving learners' listening achievements, given the observed progress by 
both skilled and less-skilled listeners. However, the role of bottom-up training could not be further confirmed until it is measured with bottom-up listening tasks (such as the dictation) as the pre- and post-listening tests, which is desirable for future work.

\section{REFERENCES}

Absalom, M., \& Rizzi, A. (2008). Comparing the outcomes of online listening versus online textbased tasks in university level Italian L2 study. ReCALL, 20(1), 55-66. doi: $10.1017 / \mathrm{S} 0958344008000517$

Baker, R., Downton, A., \& Newell, A. (1980). Simultaneous speech transcription and TV captions for the deaf. In P. A. Kolers, M. E. Wrolstad, \& H. Bouma (Eds.), Processing of visible language (pp. 445-457). New York: Plenum Press.

Bandura, A. (1994). Self-efficacy. In V. S. Ramachaudran (Ed.), Encyclopedia of Human Behavior (Vol. 4, pp. 71-81). New York: Academic Press.

Barcena, E., \& Read, T. (2015). Metacognition as scaffolding for the development of listening comprehension in a social mall app. RIED (Revista Iberoamericana de Educación a Distancia), 19(1), 103-120. doi: 10.5944/ried.19.1.14835

Berne, J. E. (1998). Examining the relationship between L2 listening research, pedagogical theory, and practice. Foreign Language Annals, 31(2), 169190. doi: 10.1111/j.1944-9720.1998.tb00566.x

Bozorgian, H. (2014). The role of metacognition in the development of EFL learners' listening skill. International Journal of Listening, 28(3), 149-161. doi: 10.1080/10904018.2013.861303

Bozorgian, H., \& Alamdari, E. F. (2018). Multimedia listening comprehension: Metacognitive instruction or metacognitive instruction through dialogic interaction. ReCALL, 30(1), 131-152. doi: $10.1017 / \mathrm{S} 0958344016000240$

Chang, A. C. S. (2009). Gains to L2 listeners from reading while listening vs. listening only in comprehending short stories. System, 37(4), 652663. doi: 10.1016/j.system

Chen, L. M., \& Zhang, R. (2010). Web-based CALL to listening comprehension. Current Issues in Fduration 13(4) Retrieved from https://cie.asu.edu/ojs/index.php/cieatasu/article/v iew/286

Cross, J. (2011). Metacognitive instruction for helping less-skilled listeners. ELT Journal, 65(4), 408416. doi: 10.1093/elt/ccq073

Cross, J., \& Vandergrift, L. (2018). Metacognitive listening strategies. In JI. Liontas (Ed.), The TESOL Encyclopedia of English Language Teaching (pp. 1-5). doi: 10.1002/9781118784235.eelt0589
Eastman, J. K. (1991). Learning to listen and comprehend: The beginning stages. System, 19(3), 179-187. doi: 10.1016/0346-251X(91)90042-N

Educational Testing Service. (2011). Reliability and comparability of TOEFL iBT scores. TOEFL $i B T$ Research Insight, 1(3), 1-8. Retrieved from https://www.ets.org/s/toefl/pdf/toefl_ibt_research _s1v3.pdf

Educational Testing Service. (2017). The official guide to the TOEFL test. New York: McGraw-Hill Education.

Fahim, M., \& Fakhri, A, E. (2014). Exploring the effect of the model of metacognitive instruction on the listening performance of EFL learners. International Journal of Research Studies in Language Learning, 3(6), 3-20. https://doi.org/10.5861/ijrsll.2014.700

Fang, X., \& Warschauer, M. (2004). Technology and curricular reform in China: A case study. TESOL Quarterly, 38(2), 301. doi: 10.2307/3588382

Field, J. (2003). Promoting perception: Lexical segmentation in L2 listening. ELT Journal, 57(4), 325-334. doi: 10.1093/elt/57.4.325

Field, J. (2008). Revising segmentation hypotheses in first and second language listening. System, 36(1), 35-51. doi: 10.1016/j.system.2007.10.003

Fredrickson, B. L. (2001). The role of positive emotions in positive psychology: The broaden-and-build theory of positive emotions. American Psychologist, 56(3), 218. Retrieved from https://www.ncbi.nlm.nih.gov/pmc/articles/PMC3 $122271 /$

Goh, C. (2008). Metacognitive instruction for second language listening development: Theory, practice and research implications. RELC Journal, 39(2), 188-213 doi: 10.1177/0033688208092184

Goh, C. C. M., \& Hu, G. (2014). Exploring the relationship between metacognitive awareness and listening performance with questionnaire data. Language Awareness, 23(3), 255-274. doi: 10.1080/09658416.2013.769558

Graham, S., \& Macaro, E. (2008). Strategy instruction in listening for lower-intermediate learners of french. Language Learning, 58(4), 747-783. doi: 10.1111/j.1467-9922.2008.00478.x

Graham, S., \& Santos, D. (2015). Strategies for second language listening: Current scenarios and improved pedagogy. London: Palgrave Macmillan.

Guest, G., Bunce, A., \& Johnson, L. (2006). How many interviews are enough? An experiment with data saturation and variability. Field Methods, 18(1), 24. doi: $10.1177 / 1525822 X 05279903$

Guo, X., Diaz, A., \& Liyanage, I. (2016). Exploring the professional agency chasm in exam-driven English language education contexts. In H. V. Rensburg \& S. O'Neill (Eds.), Deep Languages Education Policy and Practices: Stimulating languages learning - global perspectives and 
local practice (pp. 215-232). Wisconsin, USA: Deep University Press.

Hoven, D. (1999). A model for listening and viewing comprehension in multimedia environments. Language Learning and Technology, 3(1), 88-103. doi: 10.1097/SCS.0b013e3181bec71a

Hu, B., \& West, A. (2015). Exam-oriented education and implementation of education policy for migrant children in urban China. Educational Studies, 41(3), 249-267. doi: $10.1080 / 03055698.2014 .977780$

Huang, Z. (2018). Native and non-native English speaking teachers in china: Perceptions and practices. Shanghai: Shanghai Jiao Tong University Press.

Kiany, G., \& Shiramiry, E. (2002). The effect of frequent dictation on the listening comprehension ability of elementary EFL learners. TESL Canada Journal, 20(1), 57-63. doi: 10.4304/tpls.4.2.387394

Kung, S. C., \& Chuo, T. W. (2002). Students' perceptions of English learning through ESL/EFL websites. TESL-EJ, 6 (1), 1-14. Retrieved from http://www.tesl-ej.org/ej21/a2.html

Lee, J., \& Zhou, M. (2015). The Asian American Achievement Paradox. New York: Russell Sage Foundation.

LeLoup, J. W. \& Ponterio, R. (2007). Listening: You've got to be carefully taught. Language Learning \& Technology, 11 (1), 4-15. Retrieved from https://eric.ed.gov/?id=EJ813368

Lu, D. (2010). A salutary lesson from a computer-based self-access language learning project. Computer Assisted Language Learning, 23(4), 343-359. doi: 10.1080/09588221.2010.511588

Lynch, T., \& Mendelsohn, D. (2013). Listening. In T. Schmitt (Ed.), An introduction to applied linguistics (pp. 190-206). New York: Routledge.

Mahdavi, N., \& Miri, M. (2017). Co-shaping metacognitive awareness and developing listening comprehension through process-based instruction. International Journal of Listening, 33(1), 1-18. doi: $10.1080 / 10904018.2016 .1260454$

Maher, D. (2019). The use of course management systems in pre-service teacher education. In J. Keengwe (Ed.), Handbook of research on blended learning pedagogies and professional development in higher education (pp. 196-213). Hershey PA: IGI Global.

Mendelsohn, D.(1994). Learning to listen: A strategybased approach for the second-language learner. San Diego: Dominie Press.

Mendelsohn, D. (2001). Listening comprehension: We've come a long way, but, Contact, 27, 33-40. Retrieved from http://www.academia.edu/download/4565760/rese archsymposium2001.pdf\#page $=33$
Paulsen, P. (2001). New era trends and technologies in foreign language learning: An annotated bibliography. Interactive Multimedia Electronic Journal of Computer-Enhanced Learning. Retrieved from http://imej.wfu.edu/articles/2001/1/05/index.asp

Pekrun, R., Elliot, A. J., \& Maier, M. A. (2009). Achievement goals and achievement emotions: Testing a model of their joint relations with academic performance. Journal of Educational Psychology, 101(1), 115. doi: 10.1037/a0013383

Penland, J. L. (2015). Constructivist internet-blended learning and resiliency in higher education. In J. Keengwe (Ed.), Handbook of research on educational technology integration and active learning (pp. 48-61). Hershey PA: IGI Global.

Rahimi, M., \& Katal, M. (2013). The impact of metacognitive instruction on EFL learners' listening comprehension and oral language proficiency. The Journal of Teaching Skills (JTLS), 5(2), 69-90. Retrieved from

http://jtls.shirazu.ac.ir/article_1555_9229fbb278dc 5765180ef0d4060fda43.pdf

Reeves, T. C., \& Reeves, P. M. (1997). Effective dimensions of interactive learning on the World Wide Web. In B. H. Khan (Ed.), Web-Based instruction (pp. 59-66). New Jersey: Educational Technology Publications.

Robin, R. (2007). Commentary: Learner-based listening and technological authenticity. Language Learning \& Technology, 11(1), 109-115. doi: 10.1021/jp206815t

Saito, K., \& Akiyama, Y. (2018). Effects of video-based interaction on the development of second language listening comprehension ability: A longitudinal study. TESOL Quarterly, 52(1), 163176. doi: $10.1002 /$ tesq. 362

Sawaki, Y., \& Nissan, S. (2009). Criterion-related validity of the TOEFL iBT listening section. ETS Research Report Series, (1), 1-82. Retrieved from https://www.ets.org/Media/Research/pdf/RR-0902.pdf

Siegel, J. (2014). Problematising L2 listening pedagogy: The potential of process-based listening strategy instruction in the L2 classroom (Doctoral dissertation, Aston University, Birmingham, UK). Retrieved from https://research.aston.ac.uk/portal/en/theses

Siegel, J. (2015). Exploring listening strategy instruction through action research. New York: Palgrave Macmillan.

Stavredes, T. M., \& Herder, T. M. (2013). Student persistence - and teaching strategies to support it. In M. G. Moore (Ed.), Handbook of distance education (pp. 155-169). New York: Routledge.

Sun, Y. C., Chang, W. L., \& Yang, F. Y. (2011). An exploratory study of the effects of extended online thematic listening tasks on the development of listening comprehension. International Journal of 
Computer-Assisted Language Learning and Teaching, 1(3), 37-53. doi: 10.4018/ijcallt.2011070103

Tafaghodtari, M. H., \& Vandergrift, L. (2008). Second and foreign language listening: Unraveling the construct. Perceptual and Motor Skills, 107(1), 99-113. doi: 10.2466\%2Fpms.107.1.99-113

Taguchi, K. (2017). Metacognitive listening strategy instruction for EFL learners. The Bulletin of the Institute of Human Sciences(Toyo University), 19, 63-83. Retrieved from

http://www.toyo.ac.jp/uploaded/attachment/11120 8.pdf

Valiente, C., Swanson, J., \& Eisenberg, N. (2012). Linking students' emotions and academic achievement: When and why emotions matter. Child Development Perspectives, 6(2), 129-135. doi: 10.1111/j.1750-8606.2011.00192.x

Vandergrift, L. (2003a). From prediction through reflection: Guiding students: Through the Process of L2 Listening. Canadian Modern Language Review, 59(3), 425-440. doi: $10.3138 / \mathrm{cmlr} .59 .3 .425$

Vandergrift, L. (2003b). Orchestrating strategy use: Towards a model of the skilled L2 listener. Language Learning, 53, 461-494. doi: $10.1111 / 1467-9922.00232$

Vandergrift, L. (2004). Listening to learn or learning to listen? Annual Review of Applied Linguistics, 24, 3-25. doi: 10.1017/S0267190504000017

Vandergrift, L. (2007). Recent developments in second and foreign language listening comprehension research. Language Teaching, 40(3), 191-210. doi: $10.1017 / \mathrm{S} 0261444807004338$

Vandergrift, L. (2008). Learning Strategies for Listening Comprehension. In H. Stella \& L. Tim (Eds.), Language learning strategies in independent settings (pp. 84-102). Bristol: Cromwell Press Ltd.

Vandergrift, L., \& Cross, J. (2017). Replication research in L2 listening comprehension: A conceptual replication of Graham \& Macaro (2008) and an approximate replication of Vandergrift \& Tafaghodtari (2010) and Brett (1997). Language Teaching, 50(1), 80-89. doi: 10.1017/S026144481500004X

Vandergrift, L., \& Goh, C. C. (2012). Teaching and learning second language listening: Metacognition in action. New York: Routledge.

Vandergrift, L., \& Tafaghodtari, M. H. (2010). Teaching L2 learners how to listen does make a difference: An empirical study. Language Learning, 60(2), 470-497. doi: 10.1111/j.14679922.2009.00559.x

Vandergrift, L., Goh, C. C. M., Mareschal, C. J., \& Tafaghodtari, M. H. (2006). The metacognitive awareness listening questionnaire: Development and validation. Language Learning, 56(3), 431462. doi: 10.1111/j.1467-9922.2006.00373.x

Verdugo, D. \& I. A. Belmonte (2007). Using digital stories to improve listening comprehension with Spanish young learners of English. Language Learning \& Technology,11(1), 87-101. Retrieved from

http://lit.msu.edu/vol11 num1/ramirez/default.html

Wang, B. (2017). The strategies on the Chinese college student's English listening and speaking ability based on MOOC, Sino-US English Teaching, 14(2), 71-75, Retrieved from https://pdfs.semanticscholar.org/60f7/4b1755494f 3b31ebc144fc498c9eb5f77d28.pdf

Wang, W. (2016). Learning to listen: The impact of a metacognitive approach to listening instruction. Asia-Pacific Education Researcher, 25(1), 79-88. doi: 10.1007/s40299-015-0235-4 


\section{APPENDIX \\ Metacognitive Awareness Listening Questionnaire (MALQ) \\ (Adapted from Vandergrift \& Goh, 2012)}

The statements on the following page describe some strategies for listening comprehension and how you feel about listening in the language you are learning. Do you agree with them? This is not a test, so there are no "right" or "wrong" answers. By responding to these statements, you can help yourself and your teacher understand your progress in learning to listen. Please indicate your opinion after each statement. Select the number which best shows your level of agreement with the statement.

$\begin{array}{cccccc}\text { Scale } & \begin{array}{c}\text { Strongly } \\ \text { Disagree }\end{array} & \begin{array}{c}\text { Mildly } \\ \text { Disagree }\end{array} & \text { Neutral } & \begin{array}{c}\text { Mildly } \\ \text { Agree }\end{array} & \begin{array}{c}\text { Strongly } \\ \text { Agree }\end{array}\end{array}$

I like

1

2

3

4

5

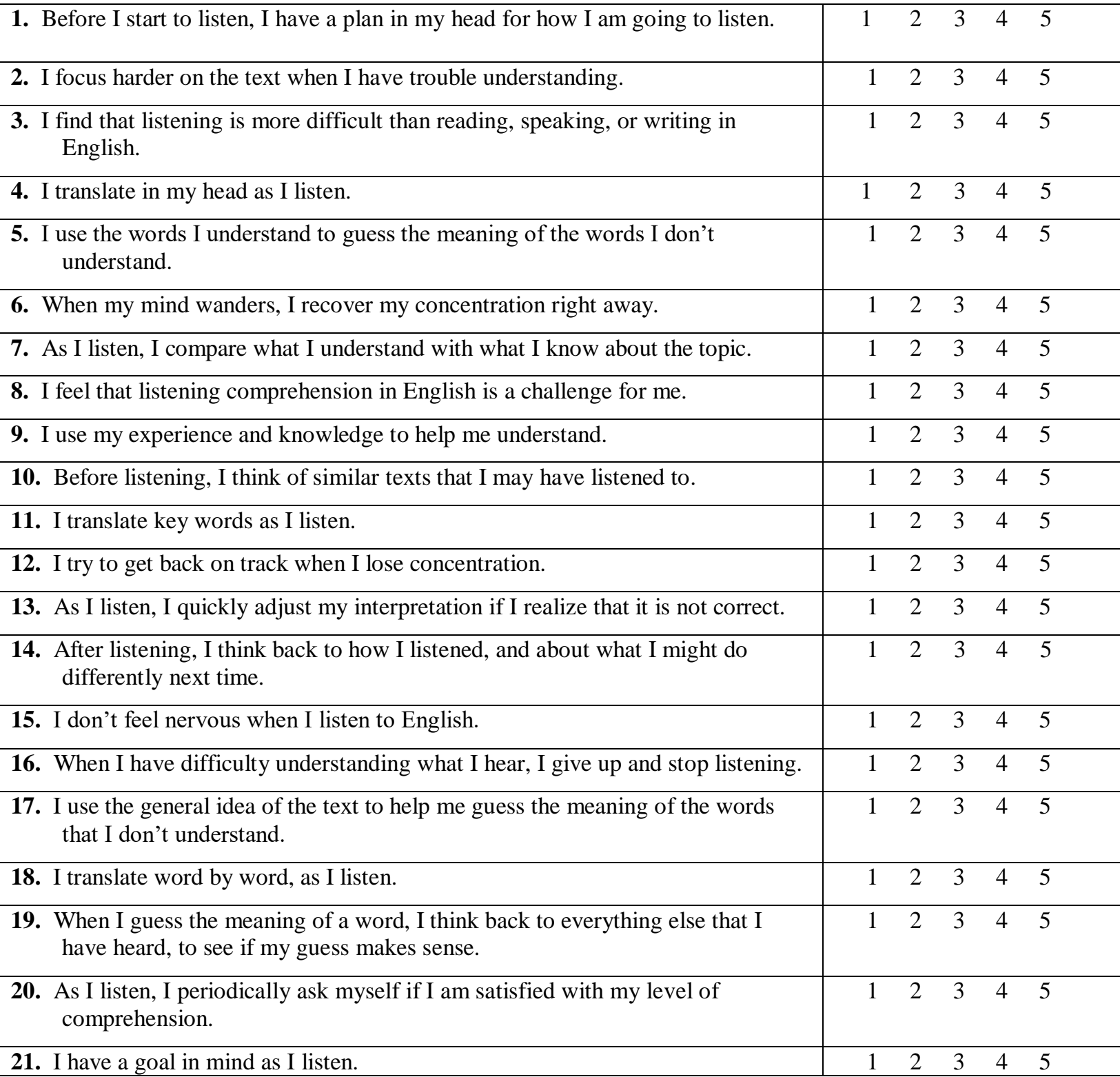

*It is noted that items $3,4,8,11,16,18$ are reversely scored. 